\title{
GERMINATION AND INFECTION OF Phakopsora pachyrhizi UNDER SIMULATED ENVIRONMENT OF THE CENTRAL AREA OF SANTA FE, ARGENTINA
}

\section{GERMINACIÓN E INFECCIÓN DE Phakopsora pachyrhizi EN AMBIENTE SIMULADO DEL ÁREA CENTRAL DE SANTA FE, ARGENTINA}

\author{
Roxana L. Maumary ${ }^{1 *}$, Rosanna N. Pioli ${ }^{2}$, Alicia Amsler ${ }^{1}$, and Antonio Ivancovich ${ }^{3}$ \\ ${ }^{1}$ Plant Pathology, Faculty of Agronomy, National University of Litoral, P. Kreder 2805, (3080) Esperanza, \\ Santa Fe, Argentina. \\ ${ }^{2}$ Instituto de Investigaciones en Ciencias Agrarias Rosario (IICAR) (CONICET-UNR), Consejo \\ Investigaciones Científicas UNR, Fitopatología, Lab. Biodiversidad Vegetal y Microbiana (BioVyM), \\ Facultad Ciencias Agrarias, UNR. Campo Exp. Villarino, CC № 14, S2125ZAA, Zavalla, Argentina. \\ ${ }^{3}$ Experimental Station of Pergamino, Instituto Nacional de Tecnología Agropecuaria (INTA), Av. \\ Frondizi (Ruta 32) Km 4,5, (2700) Pergamino, Buenos Aires, Argentina. \\ * Corresponding author E-mail address: roxanamaumary05@gmail.com
}

\begin{abstract}
Soybean asian rust (SAR) caused by the fungus Phakopsora pachyrhizi was confirmed in Argentina for the first time during the 2002-2003 growing season. Then, the disease spread to the Northern and Eastern provinces, reaching the central area of Santa Fe, which is one of the main agricultural areas of the country. However, the disease has been usually detected at the end of the growing season (late March to early April), causing little or no impact on grain and seeds production. The objectives of this study were: i) characterize, molecularly and morphologically, the isolates of $P$. pachyrhizi from this area; ii) evaluate the effect of two environmental combinations (a typical for the region and other optimal as a control) on the germination of urediniospores in laboratory conditions; and iii) assess the infecting capacity of the inoculum obtained and the disease progress promoted under greenhouse conditions. Morphologic, molecular and pathometric characteristics of uredinia and urediniospores allowed verifying $P$. pachyrhizi identity. Uredospores exposed to daily temperatures ranging from 35 to $25^{\circ} \mathrm{C}$, combined with a photoperiod and humidity conditions similar to those typical of the central area of Santa Fe during the crop cycle, decreased germination and appressoria formation and, consequently, SAR symptoms and uredinia production. These biological and epidemiological features would explain the erratic occurrence of SAR in the central producing area of Santa $\mathrm{Fe}$, Argentina. Therefore, these could be used as references to design crop management strategies aimed at decreasing disease impact in other production areas.
\end{abstract}

Key words: Phakopsora pachyrhizi, inoculum, viability, environmental conditions.

\section{RESUMEN}

La roya asiática de la soja (RAS) causado por el hongo Phakopsora pachyrhizi fue citado por primera vez en Argentina durante la campaña 2002-2003. Luego la enfermedad se diseminó a las provincias del norte del país y la región centro norte de Santa Fe. RAS ocurre usualmente al final del período reproductivo del cultivo (finales de marzo hasta principios de abril) causando poco o ningún impacto sobre la producción de granos y semillas. Los objetivos de este estudio fueron: i) caracterizar molecular y morfológicamente los aislamientos de P. pachyrhizi del área central de Santa Fe, 
ii) evaluar el efecto de dos combinaciones ambientales (una típica de la región y otra óptima como control) sobre la germinación de las urediniosporas en laboratorio; y iii) evaluar la capacidad infectiva del inóculo obtenido y el progreso de la enfermedad generado bajo condiciones de invernadero. La caracterización molecular y morfológica de uredinios y urediniosporas permitieron verificar la identidad de $P$. pachyrhizi. Las esporas expuestas al rango térmico diario $35 / 25^{\circ} \mathrm{C}$ con fotoperíodo y humedad similares a las condiciones típicas del centro de Santa Fe, disminuyeron la germinación y formación de apresorios y, en consecuencia, la aparición de síntomas y producción de uredinios de RAS. Los resultados biológicos y epidemiológicos obtenidos podrían explicar la baja frecuencia de ocurrencia de RAS en la región central de Santa Fe, Argentina, y pueden ser tomados como referencia al diseñar estrategias de manejo de cultivo orientadas a minimizar el impacto de la enfermedad en otras áreas productivas.

Palabras clave: Phakopsora pachyrhizi, inóculo, viabilidad, ambiente.

\section{INTRODUCTION}

Phakopsora pachyrhizi fungus (Syd. \& P. Syd.), teleomorph Malupa sojae (Henn.) Ono, Buriticá \& Hennen), has been identified as the main causal agent of Soybean Asian Rust (SAR). It belongs to the Phylum Basidiomycota, Class Urediniomycete, Order Uredinales, Family Melampsoraceae (Ono et al., 1992). Under favorable environmental conditions, SAR produces severe foliar symptoms, early defoliation and a decrease in the number and weight of seeds, mainly during the critical period of soybean growth (R1- flowering to R6- full pods) (Bromfield, 1984; Miles et al., 2003). In Argentina, P. pachyrhizi was first found in Misiones Province during the 2002/2003 growing season (Rossi, 2002). Afterwards, SAR spread out to other important production areas of the northern region (Carmona et al., 2004) and Santa Fe Province (Herzog y Astegiano, 2004; Pioli et al., 2005).

Several studies performed on soybean regions around the world reported that the germination process of urediniospores required humidity higher than $80 \%$ combined with temperatures ranging from $16^{\circ} \mathrm{C}$ to $24^{\circ} \mathrm{C}$ and periods of at least 6 hours of leaf wetness (Marchetti et al., 1976). Under favorable conditions during a certain time period, urediniospores would achieve symptomatic lesions promoting secondary infections each 5 to 10 days successively (Yang, 2002). In Brazil, urediniospores released from mature uredinia preserved their viability during 28 to 50 days (Yorinori, 2004). P. pachyrhizi can also induce the formation of appressoria to penetrate directly through the soybean epidermal cells (Hoppe and Koch, 1989). The formation of non-specific appressoria constitutes a relevant pathogenic capacity because this event would allow invading a wide range of hosts (Miles et al., 2003).

However, disease occurrence in the central region of Santa Fe province, in which the average temperature ranges from 35 to $25^{\circ} \mathrm{C}$ (daynight), has been less frequent than other soybean producing areas of Argentina. The hypothesis of work was that effectiveness of the fungal infection depends on the capacity to penetrate plant tissue, germination and viability of urediniospores, and the environmental conditions associated with the soybean-P. pachyrhizi interaction. Local biological studies on the $P$. pachyrhizi infection process were not abundant. Therefore, the objectives of this work were: i) characterize molecularly and morphologically $P$. pachyrhizi isolates obtained from the central area of Santa Fe; ii) evaluate the effect of two simulated temperature conditions (typical temperature for the region studied and optimal temperature as a control) on urediniospore germination and appressoria formation under laboratory conditions; and iii) assess the infecting capacity of $P$. pachyrhizi inoculum and the progress of the disease under greenhouse conditions.

\section{MATERIALS AND METHODS}

Collection of leaves with symptoms of Soybean asiatic rust. Forty leaflets with typical lesions caused by natural infection of $P$. pachyrhizi were collected from ten plots located in four locations (Crespo, San Justo, Emilia and Esperanza) of the central area $\left(30^{\circ} 47^{\prime} 2^{\prime \prime} \mathrm{S}, 60^{\circ} 35^{\prime} 27^{\prime \prime} \mathrm{W}\right)$, Santa Fe Province, Argentina. Three composited samples (replications) were obtained per plot and location and kept at $-20^{\circ} \mathrm{C}$ until their processing. Thirty to forty urediniospores $(\mathrm{u})$ were extracted from uredinia of similar development for each replication, while different leaflets were obtained for each replication, plot and location. Thus, groups of fresh urediniospora were obtained to be evaluated through molecular, morphological and pathogenic characterizations.

Molecular identification of Phakopsora pachyrhizi isolates. Five to $10 \mathrm{mg}$ of urediniospores from composite samples, corresponding to each location of the central area of Santa Fe, were used for the molecular characterization. DNA extraction was performed using a specific DNA Extraction Kit (Nucleon Phyto Pure, GE 
Healthcare Life Sciences), according to the manufacturer's instructions. An amplification with universal primers ITS4 (5'TCCTCCGCTTATTGATATGC3') and ITS5 (5'GGAAGTAAAAGTCGTAACAAGG3') was performed as an additional experimental control of DNA quality (White et al., 1990). Then, the taxonomic identification was conducted using conventional PCR primers based on sequence analysis of the internal transcribed region (ITS) of ribosomal DNA (rDNA) of P. pachyrhizi, according to Frederick et al. (2002).

\section{Morphological identification of Phakopsora} pachyrhizi isolates. Those samples molecularly identified as $P$. pachyrhizi, were also morphologically characterized. Thereby, macro and micro-morphology of uredinia and urediniospores (30 to $40 \mathrm{u}$ per replication; total $\mathrm{n} \sim 90$ to $120 \mathrm{u}$ per location) were evaluated using a stereoscopic (40x) and optical microscope (400-1000x) (Hartman et al., 1999). Pathometric characteristics were observed with a calibrated micrometric ocular (Pioli et al., 2005; Maumary et al., 2013). Data were statistically analyzed using an average comparison test with a $95.0 \%$ confidence level (Campbell and Madden, 1990).

Histopathological sections of soybean rust lesions were fixed and kept in ethanol/acetic acid/ formaldehyde/water (50:5:30:15) at room temperature before use. Samples were dehydrated in successive ethanol solutions and clarified with xylol; then, they were embedded in paraffin. The solidified samples were cut in sections of $10 \mu \mathrm{m}$ thick with rotational microtome and stained with safranin-fast green. Finally, they were mounted in Canadian balsam on glass slides ( $\mathrm{D}^{\prime}$ Ambrogio, 1986). Microphotographs were taken with a D-560 Zoom 3X optical zoom (Olympus camera, Tokyo, Japan) (Maumary et al., 2013).

Once local $P$. pachyrhizi isolates were identified both morphologically and molecularly, their urediniospores were exposed to two thermal ranges (as it is described below) to evaluate their effect on germination and viability of uredospores. Evaluations were performed in vitro, under laboratory conditions and in vivo, to analyze the infective capacity of spores and disease progress during the pathogenicity assay performed in under greenhouse conditions (Furtado et al., 2008).

Effect of two simulated thermal conditions on $P$. pachyrhizi germination under laboratory conditions. A combination of humidity $(\mathrm{H})$ higher than $80 \%$ and a photoperiod $(\mathrm{P})$ of $16: 8$-hour light-dark alternation was chosen to complement the two thermal options proposed to evaluate urediniospore germination. This H-P combina- tion is common during soybean growth in the central region of Santa Fe, and it has been considered as favorable to germination by Hoppe and Koch (1989); Leiva et al. (2004) and Zambenedetti et al. (2007). Treatment I (Treat.) was performed based on a constant temperature of $23^{\circ} \mathrm{C}$, which has been reported as optimal and conductive for SAR infection (Tan et al., 1994; Bonde et al. 2006). Treatment II simulated a typical range between $35^{\circ} \mathrm{C}$ (as average maximum daytime temperature) $\left({ }^{\circ} \mathrm{T}\right)$ and $25^{\circ} \mathrm{C}$ (as average maximum night temperature), present during the soybean reproductive period in the area evaluated. From symptomatic leaves with SAR, uredinia and urediniospores were extracted manually as it was previously described. Groups of 150 to 200 fresh urediniospores $(\mathrm{u})$ were extracted from uredinia and constituted composited samples of $7,5 \times 10^{2}$ to $1,6 \times 10^{3} \mathrm{u}$ per replication, estimated by hemocytometer (Bonde et al., 2006; Maumary et al., 2006). Thus, $1,1 \times 10^{3} \pm 3,7 \times 10^{2} \mathrm{u}$ and $1,02 \times 10^{3} \pm 3,9 \times 10^{2} \mathrm{u}$, respectively, were kept in plastic microtubes of 1 $\mathrm{mL}$, tightly sealed and preserved at $-20^{\circ} \mathrm{C}$, until germination was evaluated under Treat. I and II conditions (Maumary et al., 2006; 2013).

The germination process and time in which the spores remained alive were evaluated and recognized through two biological events: i) the growth of a germination hypha, and later ii) the observation of an appressoria. A urediniospore was considered completely germinated when the length of the germination hypha was at least as long as its largest diameter (Yorinori, 2004). Germination and viability of the urediniospores were evaluated at 6 and 18 hours post incubation and then every 2 days during the subsequent 10 incubation days according to Yang (2002) and Park et al. (2008). From the composite sample assigned to each Treat. (I and II), 4 subsamples per evaluation time were resuspended in $1 \mathrm{~mL}$ of sterilized distilled water with $0.01 \%$ Tween 20 into an excavated slide to be evaluated (Maumary, 2013). Then, subsamples corresponding to each moment and treatment were evaluated using a hemacytometer (100-400 magnification) to evaluate germinated urediniospores $(\mathrm{GU})$ percentage. The GU \% was estimated as: (germinated urediniospore number / total number of urediniospores counted on 16 visual fields with 4 replications) $x 100$. Number of GU between evaluation times were recognized by staining of the active (alive) germinative hyphas with cotton blue (Furtado et al., 2008; Park et al., 2008).

Infective process of $P$. pachyrhizi and disease progress of SAR under greenhouse conditions. Those samples of uredospores exposed to the best combination T-H-P for germination, were used as 
inoculum for promoting the infection process, in vivo, under greenhouse conditions (pathogenicity test, third Koch Postulate) (Maumary, 2013). Trials were performed based on two replications of five plants each of a soybean cultivar (Madurity Group V) used in the central area of Santa Fe. Inoculation was made when the second trifoliate leaf was fully expanded (Fehr and Caviness, 1977). Leaflets were previously soaked with sterilized water and then air-dried. Then, urediospores were distributed on the adaxial surface of leaves using the spatula-slide technique (Dhingra and Sinclair, 1985; Furtado et al., 2008). Inoculated plants were observed daily and weekly after symptom detection using a non-destructive method. Lesions were counted on four sections of $0.25 \mathrm{~cm}^{2}$ each, which constituted $1 \mathrm{~cm}^{2}$ of leaf surface per leaflet. Variables analyzed were: i) incubation period (number of days since inoculation moment and observation of the first little clorotic blotches symptoms); ii) latency period (number of days since inoculation and observation of the first uredinia signs); iii) mean number of lesions with signs developed per $\mathrm{cm}^{2}$, and iv) the mean number of uredinia per lesion of SAR (Pioli et al., 2005; Maumary et al., 2006). The disease progress was assessed on 10 random observations per plant and 5 evaluated plants $(n=50)$ per replication. SAR was calculated based on a scale of 6 degrees of SAR severity designed with the 2-LOG Program (v.1.0), where $0=0 \% ; 1=0.1$ to $3 \% ; 2=$ 3.1 to $6 \% ; 3=6.1$ to $13 \% ; 4=13.1$ to $27 \%$, and 5 $=27.1$ to $40 \%$. The mean number of uredinia per lesion of SAR was calculated on 15-20 lesions of $P$. pachyrhizi per plant and five plants evaluated $(\mathrm{n}=$ 90-100) (Maumary, 2013). Data corresponding to three different moments of evaluation were statistically analyzed by Duncan Test with a 95.0\% confidence level.

\section{RESULTS AND DISCUSSION}

\section{Molecular identification of Phakopsora} pachyrhizi isolates. Fig. 1 shows the agarose gel obtained to validate molecularly the identity of 10 samples of $P$. pachyrhizi collected from four locations of the central region of Santa Fe province (SF). Molecular weight marker (Mpm) (100 $\mathrm{bp}$, Promega) points out the band profile. Lanes 1 and 12 corresponding to two positive controls of P. pachyrhizi (Dr. E. Guillín, Laboratorio Estación Experimental INTA Castelar); Lanes 2, 3, 4, 5 corresponding to other fungal genus used as experimental controls; Lanes 6, 7, 8, 9, 13, 14, 15, 16, 17 and 18 corresponding to different samples of P. pachyrhizi obtained from Crespo, San Justo, Emilia and Esperanza (central region of Santa $\mathrm{Fe}$ ). Lanes 19 and 20 corresponding to P. meibomi- ae (Lab. CICVA, EE INTA Castelar) and Lanes 10 and 21 (negative control without DNA).

Only those samples that amplified and revealed a band of $330 \mathrm{bp}$ under the methodological conditions described by Frederick et al. (2002) were validated as $P$. pachyrhizi. Thus, the positive controls of $P$. pachyrhizi (lanes 1,12 ) and four isolates from Crespo, San Justo, Emilia and Esperanza locations of the central region of Santa Fe (Lanes 6, 9, 13 and 18, respectively), showed the specific band $(330 \mathrm{bp})$ and their identity was validated as $P$. pachyrhizi. The negative results in this gel (Lanes 7, 8, 14, 15, 16 and 17) could be due to factors as the storage time and physiological age of the leaves collected.

Subsequently, the four local isolates identified as P. pachyrhizi were included for performing the morphological study and pathogenic trials to achieve the objectives.

Morphological identification of local $P$. pachyrhizi. Morphological characterization was made on samples with symptoms and signs (uredinia and uredospores) of $P$. pachyrhizi from Crespo, San Justo, Emilia y Esperanza (molecularly validated) (Fig. 2). Leaf symptoms caused by $P$. pachyrhizi were observed as pale grey-yellowish lesions that later changed to tan or brown color. Fungal fruit bodies or uredinia grew solitary or grouped on the lesions and most of them were scattered on the lower leaflet surface (hypophyllous). Uredinia showed pale cinnamon color changing to brownish-brown with the age; these immature fructifications were initially sub-epidermal but later became erumpent and rounded-shaped according to previous reports (Hartman et al., 1999; Miles et al., 2003; Pioli et al., 2005).

Histopathological sections of immature uredinia showed an upper opening, not still differentiated. However, mycrophotographs of uredinia in different grow stages put in evidence some structural changes (Fig. 2 a-d). Likewise, matured uredinia were conic to round with abundant peripheral paraphyses surrounding the central upper opening. Later, urediniospores were released through this opening (Fig. 2 b-d). Urediniospores were sessile, hyaline to light yellow-brown, obovoid to broadly ellipsoid-shaped and they showed an external wall slightly echinulated (Fig. 4). The average length and width of urediniospores and respective standard errors were $26 \pm$ 0.7 and $17.3 \pm 1.3 \mu \mathrm{m}$, respectively. These results are in agreement with the length (18 to $34 \mu \mathrm{m})$ and width (15 to $24 \mu \mathrm{m})$ reported by Ono et al. (1992). Spore length showed no significant differences $(\mathrm{F}=1.14 ; \mathrm{p}<0.33)$, while spore width was a more variable measurement. These morphologi- 


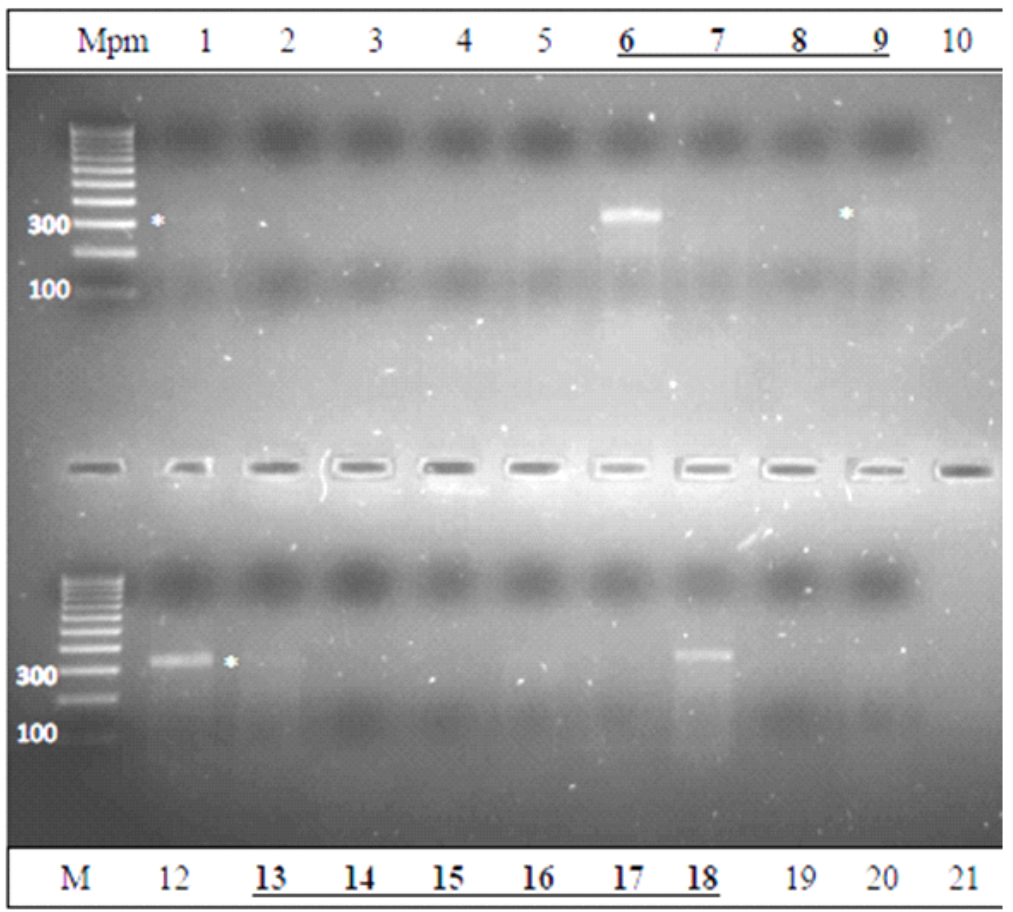

Fig. 1. Agarose gel shows band profile of $P$. pachyrhizi isolates from locations of the central region of Santa Fe, Argentina. Molecular weight marker (Mpm), Lanes 1 and 12 refer to two positive controls of $P$. pachyrhizi; Lanes $2,3,4,5$ corresponding to other fungal genus used as experimental controls; Lanes $6,7,8,9,13,14,15,16,17$ and 18 corresponding to different samples of $P$. pachyrhizi obtained from Crespo, San Justo, Emilia and Esperanza (central region of Santa Fe). Lanes 19 and 20 corresponding to P. meibomiae (Lab. CICVA EE INTA Castelar) and Lanes 10 and 21 (negative control without DNA).

Fig. 1. El gel de agarosa muestra el perfil de bandas de aislamientos de P. pachyrhizi de diferentes localidades de la región central de Santa Fe, Argentina. Marcador de Peso Molecular (Mpm), Líneas 1 y 12 refieren a dos controles positivos de $P$. pachyrhizi; Líneas 2, 3, 4, 5 corresponden a otros géneros fúngicos usados como controles experimentales; Líneas $6,7,8,9,13,14,15,16$, 17 y 18 corresponden a diferentes muestras de $P$. pachyrhizi obtenidos en Crespo, San Justo, Emilia and Esperanza (región central of Santa Fe). Líneas 19 y 20 correspondieron a to P. meibomiae (Lab. CICVA EE INTA Castelar) y Líneas 10 y 21 (control negativo sin DNA).

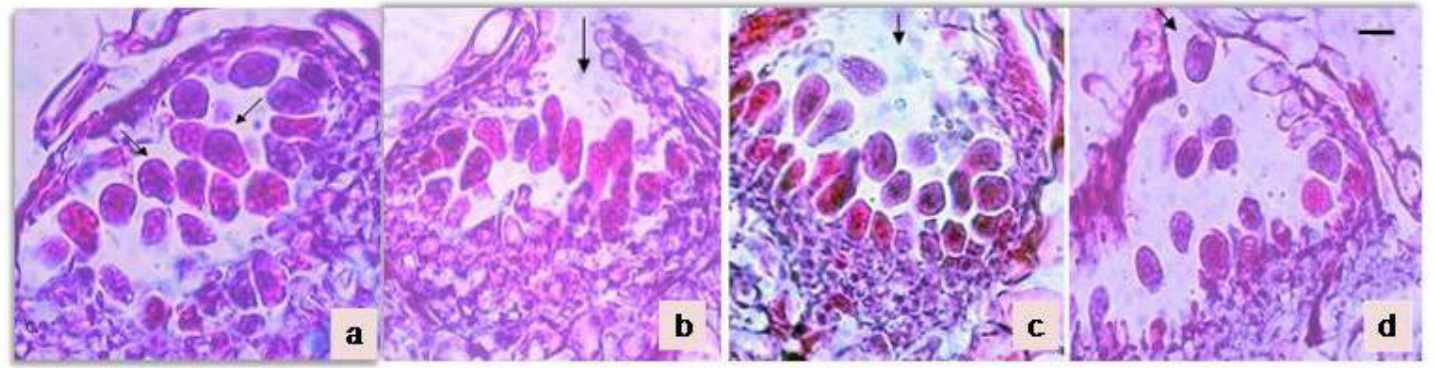

Fig. 2. Leaf sections showing fruiting bodies (uredinia) of Phakopsora pachyrhizi. a. Inmature uredinium; b-c. mature uredinium with top opening and releasing urediniospore

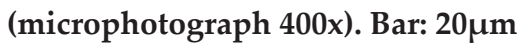

Fig. 2. Secciones foliares que muestran cuerpos fructíferos (uredinia) of Phakopsora pachyrhizi. a. Uredinio inmaduro; b-c. Uredinios imaduros con poro apical y liberación de urediniosporas. Barra: $20 \mu \mathrm{m}$ 


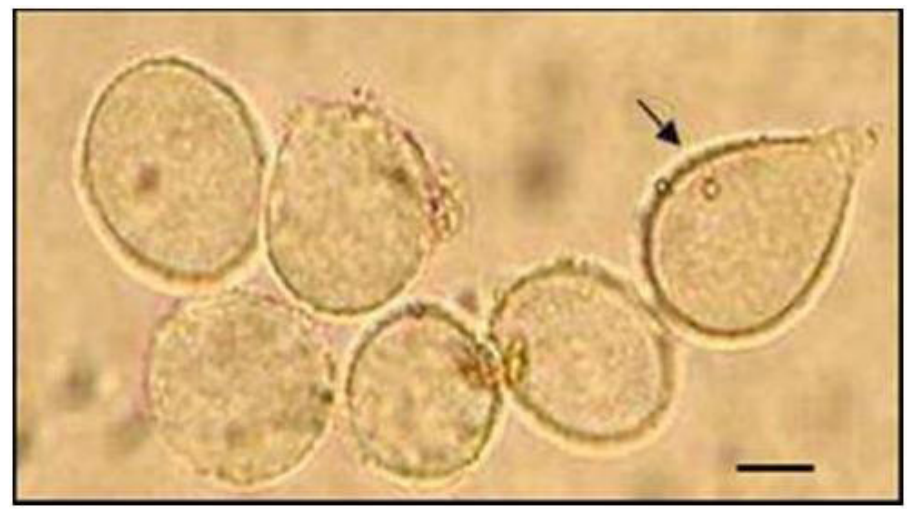

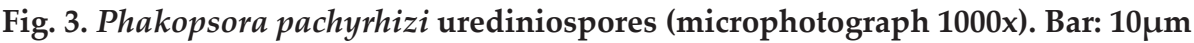
Fig. 3. Urediniosporas de Phakopsora pachyrhizi (microphotograph 1000x). Bar: 10um

cal and molecular results validated the identity of $P$. pachyrhizi isolates obtained from four locations of the central area of Santa Fe.

Effect of two simulated thermal conditions on the germination of $P$. pachyrhizi under laboratory conditions. In both experimental conditions, germination started with the observation of a small germinative tube (mucron); then hypha emerged through of a unique germ pore placed on the external wall or episporium (Fig. 4a). These observations were similar to those reported by Parck et al. (2008), but they differ from other studies that reported 2 to 10 germ pores (mostly 6) from each spore (Ono et al., 1992).

Germination started at 6 hours after incubation under a constant temperature of $23^{\circ} \mathrm{C}$ (Treat. I), while it was delayed under the higher thermal range (Treat. II). Mean length of the germinative hyphae (or tube) was different between treatments, reaching $46.0 \pm 10 \mu \mathrm{m}$ for $23^{\circ} \mathrm{C}$ constant temperature (Fig. 4a) and $11.5 \pm 8 \mu \mathrm{m}$ for $35 / 25^{\circ} \mathrm{C}$ range, respectively. Germination showed neither a directional growth nor a conserved pattern during the growth of germinative tubes.

Appressoria were developed at the top of germinative hyphaes (Fig. 4b). This event constitutes a relevant biological strategy during the process of infection and colonization because these structures promote plant tissues entry (Miles et al., 2003; Voegele and Mendgen, 2003). The intimate interaction existing between the appressorium and leaflet tissue could explain the infrequent production of these structures under in vitro conditions (Voegele et al., 2001; Ayliffe et al., 2002). A $100 \%$ of the germinated hyphae $(n=90)$ developed an appressorium under $23^{\circ} \mathrm{C}$ constant temperature, while only $20 \%(n=18)$ produced it under a temperature range of $35-25^{\circ} \mathrm{C}$. Appressoria constitute an important biological tool to up- take nutrients and also overcome specifically the structural defense of plants. Ayliffe et al. (2002) related these structures to biosynthetic pathways involved in biotrophy. To have knowledge of the pathogen and host metabolism interaction, it might be useful to look for and incorporate resistance to plants against pathogens (Jennings et al., 2002).

Additionally, small germinative tubes were observed at $6 \mathrm{~h}$ during the first day after inoculation (dai), while the first GU\% values were recorded at $18 \mathrm{~h}$. Subsequent evaluations were estimated each 2 days (during 10 dai) (Fig. 5). Mean values of $\mathrm{GU} \%$ and respective standard deviations obtained from Treat. I (optimal) and Treat II. (typical thermal range of central area of Santa Fe) are showed in Fig. 5a and Fig. 5b, respectively.

Urediniospores exposed to constant temperature $\left(23^{\circ} \mathrm{C}\right.$, Treat. I) showed $91.4 \mathrm{GU} \%$ at 18 hai. From this first value, GU\% began decreasing and showed drops of $0.6 ; 4.4$ to $22.6 \%$ at 2 nd; 4 th and 6th dai, respectively (Fig. 5a), pointing out successive losses of spore viability. Nevertheless, the highest rate of decreasing viability was 39.3\% and it was recorded between the 6th $(70.7 \%)$ and 8 th dai $(31.4 \%$ GU). Meanwhile the accumulated drop was $81.2 \%$ on the 10th dai (Fig. 5a).

GU\% under the thermal range of the central area of Santa $\mathrm{Fe}\left(35-25^{\circ} \mathrm{C}\right.$ day/night alternation, Treat. II) was $93.8 \%$ at $18 \mathrm{~h}$ of incubation. Only the $7.4 \%$ GU was estimated at 2 dai, pointing out a negative slope of $86.4 \%$ GU and a sharp drop of the viability. Finally, the accumulated drop was 96.5 and $100 \%$ GU at 6 th and $8^{\text {th }}$ dai, respectively (Fig. 5b).

A negative relation between the viability of germinated urediniospores and exposition time was found for both environmental combinations evaluated (Fig. 5). Maximum and minimum values of GU obtained during 10 dai for treatments 


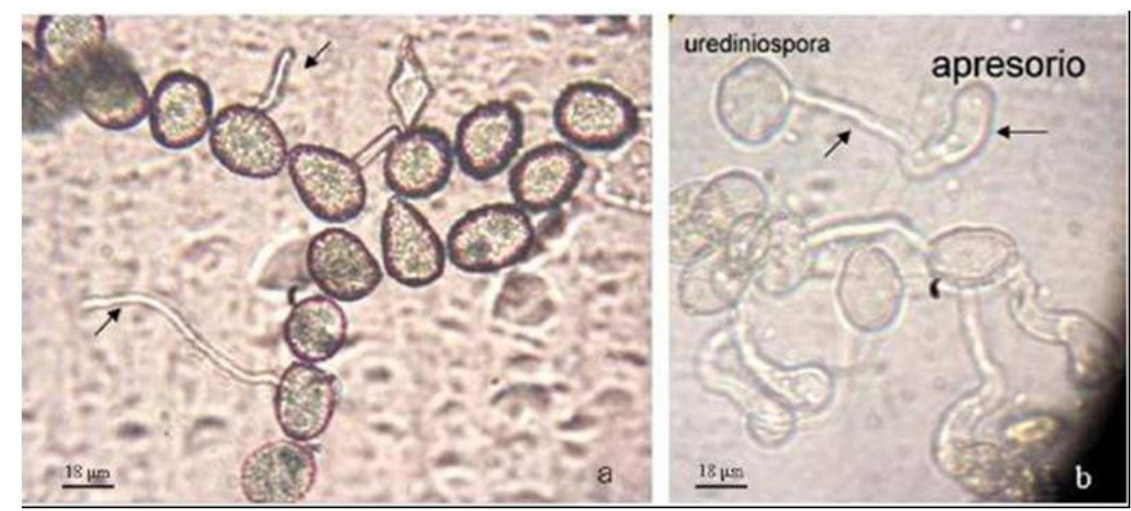

Fig. 4. a. Germinated urediniospores of $P$. pachyrhizi with a small tube or germination hypha emerging through a unique germ pore in the external wall or episporium; $b$. Urediniospores with appressoria developed at the top of each germination hyphae. Bar: $18 \mu \mathrm{m}$.

Fig. 4. a. Urediniosporas germinadas de $P$. pachyrhizi con un pequeño tubo o hifa germinación emergente a través de un poro germinal único en la pared externa o episporium; $b$. Urediniosporas con apresorios desarrollados en la parte superior de cada hifa de germinación. Bar: $18 \mu \mathrm{m}$.

I and II were 91.4 to $93.8 \%$ and 17.2 to $0.0 \%$ GU, respectively.

When comparing both experimental conditions, it was observed that a constant temperature of $23^{\circ} \mathrm{C}$ combined with high humidity and a photoperiod of 16:8-hour light-dark alternation was the most favorable environment for both biological events (spore germination and appressorium). These results agreed with Bonde et al. (2007) who reported that the optimum temperature range for tube length was between 21 and $24^{\circ} \mathrm{C}$. Meanwhile, the day-thermal range of 35 and $25^{\circ} \mathrm{C}$ decreased significantly the viability of SAR urediniospores and, consequently, it could restrict the viable inoculum production. This information may be useful for plant breeding programs based on inoculation techniques to select and incorporate P. packyrhizi resistance (Marchetti et al., 1975; Alves et al., 1998; Furtado et al., 2008).

\section{P. pachyrhizi infection and progress of RAS under greenhouse conditions.}

Environmental conditions performed in both experiments modified differentially the infection capacity of urediniospores and disease progress of SAR in greenhouse conditions. SAR lesions were observed only surrounding the contact point under simulating field conditions of the central area of Santa Fe ( 35 to $25^{\circ} \mathrm{C}$, Treat. II). This occurred because this temperature range limited germination spores and infection and colonization by Phakopsora. Meanwhile, those urediniospores exposed to a constant temperature of $23^{\circ} \mathrm{C}$ with the same combination (humidity higher than $80 \%$ and a photoperiod of $16: 8$-h light-dark alternation) (Treat. I) produced effective infections. SAR lesions (symptoms) were observed after an incubation of 8 dai and lesion size was $2.5 \pm 0.5 \mathrm{~mm}^{2}$. Latency period finished at 9 and 10 dai when solitary and grouped uredinia of $P$. pachyrhizi (signs) were observed approximately on $50 \%$ of SAR lesions. Mean number of lesions with signs per $\mathrm{cm}^{2}$ was $9.8 \mathrm{~cm}^{-2} \pm 1.4$ at 18 dai (Table 1). Disease progress was assessed at $8-10,18$ and 31 dai. Thus, SAR started with 0.1 to $3 \%$ (10 dai) until 6.1 to $13 \%$ severity (31 dai) (Table 2), showing that severity had the highest increase prior to the second evaluation and remained the same during the third. In addition, mean number of uredinia per lesion was $2.9 \pm 1.1$ recorded at 18 dai (Table 2).

The results obtained from both Treat. I y II confirmed that a constant temperature of $23^{\circ} \mathrm{C}$ - humidity higher than $80 \%$ and a photoperiod of 16:8-h light-dark alternation promoted a good germination level and effective infections from $P$. pachyrhizi inoculums obtained in the central area of Santa Fe, Argentina. Meanwhile, inoculations carried out with inoculum exposed to daily temperature ranging between 35 and $25^{\circ} \mathrm{C}$, typical of the central area of Santa Fe, did not produce effective infections, symptoms and uredinia of SAR. On this respect, Tan et al. (1994) reported that the penetration from germination tubes occurred between 22 to $26^{\circ} \mathrm{C}$, but no penetration occurred at $28^{\circ} \mathrm{C}$ or higher, suggesting that natural infections of SAR do not occur with temperatures above $27^{\circ} \mathrm{C}$. However, some authors have shown 


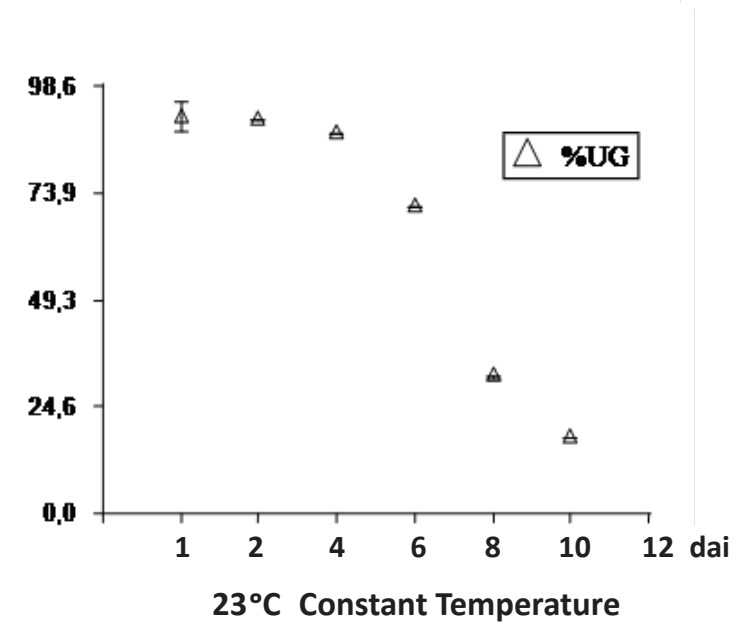

A

B

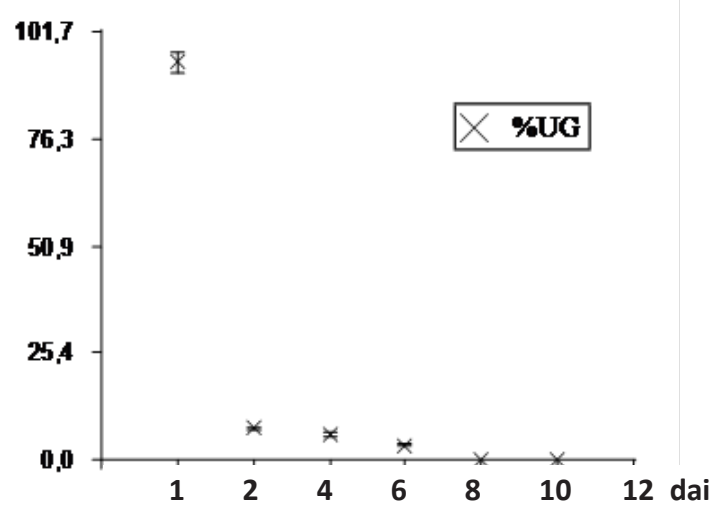

$35-25^{\circ} \mathrm{C}$ day:night Temperature alternancy

Fig. 5. Temporal progress of the germination process of Phakopsora pachyrhizi urediniospores, expressed as mean values of germinated urediniospores (\% GU) registered every 2 days after beginning incubation (dab) during 10 days. Data were registered in vitro under two thermal conditions: A: under $23^{\circ} \mathrm{C}$ constant (Treatment I), and B: $35-25^{\circ} \mathrm{C}$ day:night alternancy (Treatment II), both with a same photoperiod (16:8 $\mathrm{h}$, light-dark alternancy) and humidity level

a lack of correlation when comparing spore germination in vitro and infected area because the infection process also depends on the host compatibility and the environmental conditions (Lucas and Knights, 1987; Furtado et al., 2008). However, Sousa et al. (2006) pointed out an evident effect of the temperature range on the production, germination and viability of $P$. pachyrhizi spores. Consequently, the results obtained in the present study could explain the low frequency and occurrence of SAR caused by P. pachyrhizi in the central-north region of Santa Fe, Argentina.

\section{CONCLUSIONS}

a. Molecular and morphological characterizations allowed validating the identity of $P$. pachyrhizi.

b. The effect of the two evaluated thermal conditions on the germination of uredospores and appressoria was differentially evident under in vitro conditions, even when the combination of humidity higher than $80 \%$ and photoperiod of 16:8 $\mathrm{h}$ light-dark alternation was the same.

c. The daily thermal range of $35-25^{\circ} \mathrm{C}$, typical of the central area of Santa Fe, reduced germina- 
Table 1. Latency period expressed as number of days from inoculation time until observation of Phakopsora pachyrhizi uredinia and mean number of lesions with signs per $\mathrm{cm}^{2}$ produced by inoculum incubated under constant $23^{\circ} \mathrm{C}$ combined with humidity $>80 \%$ and a photoperiod of 16:8 h light-dark alternation under greenhouse conditions.

Tabla 1. Período de latencia expresado como número de días desde la inoculación y la observación de uredinios of Phakopsora pachyrhizi y número promedio de lesiones con signos por $\mathrm{cm}^{2}$ producidas con inóculo incubado a temperatura constante de $23^{\circ} \mathrm{C}$ combinada con humedad $>80 \%$ y fotoperíodo de 16:8 h (alternancia día-noche), en condiciones de invernadero.

\begin{tabular}{ccc}
\hline Evaluated plants & $\begin{array}{c}\text { Mean latency period } \\
\text { dai }^{\mathbf{1}}\end{array}$ & $\begin{array}{c}\text { Mean number of lesions } \\
\text { signs } \mathbf{~ c m}^{-2}\end{array}$ \\
\hline 1 & 10 & $8.5 \pm 1.1$ \\
2 & 9 & $12.0 \pm 1.7$ \\
3 & 9 & $10.0 \pm 1.2$ \\
4 & 10 & $8.5 \pm 1.3$ \\
5 & 10 & $10.0 \pm 1.2$ \\
Mean & & $9.8 \pm 1.4$ \\
\hline
\end{tabular}

${ }^{1}$ dai: days after inoculation.

Mean number of lesions with signs $\mathrm{cm}^{-2}$ observed on the leave surface was calculated on 10 random observations/plant and 5 evaluated plants $(n=50)$, per replication. Data were recorded at 18 dai.

Table 2. Severity degree and mean number of uredinia per lesion of Phakopsora pachyrhizi recorded at 10, 18 and 31 days after inoculation (dai) in greenhouse under $23^{\circ} \mathrm{C}$ temperature, $16: 8 \mathrm{~h}$ photoperiod and high humidity.

Tabla 2. Grado de severidad y número promedio de uredinios por lesión de Phakopsora pachyrhizi registrados a los 10, 18 y 31 días post inoculación (dai) en invernadero, bajo $23^{\circ} \mathrm{C}$ de temperatura constante, combinada con un fotoperíodo de 16:8 h día/noche y alta humedad.

\begin{tabular}{ccc}
\hline Days after inoculation & $\begin{array}{c}\text { Mean value of } \\
\text { uredinia/lesion }\end{array}$ & $\begin{array}{c}\text { Severity } \\
\text { degree }^{\mathbf{2}}\end{array}$ \\
\hline 8 and 10 & $1.7 \pm 1.0 \mathrm{a}$ & 1 \\
18 & $2.9 \pm 0.9 \mathrm{~b}$ & 3 \\
31 & $2.8 \pm 1.3 \mathrm{~b}$ & 3 \\
\hline
\end{tabular}

${ }^{1}$ In each date or moment of evaluation, mean number of uredinia/lesion was calculated on the observation of 15-20 lesions of Phakopsora pachyrhizi per plant and five plants evaluated $(\mathrm{n}=90-100)$. Data were statistically analyzed and compared by Duncan test.

${ }^{2}$ Severity corresponding to three different moments of evaluation were calculated on 10 random observations/plant and 5 evaluated plants $(n=50)$, per replication. Disease progress were calculated basing on a scale of 6 degrees of SAR severity, where $0=0 \% ; 1=0.1$ to $3 \% ; 2=3.1$ to $6 \% ; 3=6.1$ to $13 \% ; 4=13.1$ to $27 \%$, and $5=27.1$ to $40 \%$ (Maumary, 2013). Data were statistically analyzed by Duncan Test.

tion and appressorium formation, while the constant temperature of $23^{\circ} \mathrm{C}$ was the best combination to induce both biological variables.

d. Similar effects were observed under greenhouse condition.

e. Consequently, the simulation of the natural conditions of fields of the central area of Santa Fe, did not stimulate effective infections of SAR.

$\mathrm{f}$. These bio-assays confirm the importance of temperature on germination and viability of $P$. pachyrhizi spores.

g. These results would explain the low frequency of SAR occurrence in this crop production area of Argentina and constitute a reference for proposals based on crop management strategies adapted to different environments.

\section{LITERATURE CITED}

Alves, S.B., J.E. Almeida, A. Minor Jr., e E.L.F. Alves. 1998. Técnicas de laboratorio. p. 637710. In S.B. Alves (ed.). Controle microbiano de insetos. Fundação de Estudos Agrários Luiz de Queiroz (FEALQ), Piracicaba, Sao Paulo, Brasil. 
Ayliffe, M.A., J.K. Roberts, H.J. Mitchell, R. Zhang, G.J. Lawrence, J.G. Ellis, and T.J. Pryor. 2002. A plant gene up-regulated at rust infection sites. Plant Physiology 129:169-180.

Bonde, M.R., S.E. Nester, C.N. Austin, C.L. Stone, and R.D. Frederick. 2006. Evaluation of virulence of Phakopsora pachyrhizi and P.meibomiae isolates. Plant Disease 90(6):708-716.

Bonde, M.R., D.K. Berner, S.E. Nester, and R.D. Frederick. 2007. Effects of temperature on urediniospore germination, germ tube growth, and initiation of infection in soybean by Phakopsora isolates. Phytopathology 97:997-1003.

Bromfield, K.R. 1984. Soybean rust. Monography (APS11). American Phytopathology Society, St. Paul, Minnesota, USA.

Caldwell, P.M., and M.C. Laren. 2004. Soybean rust research in South Africa. p. 354-361. In Proceeding of the VII World Soybean Forum, IV International Soybean Processing and Utilization Conference, III Congresso Brasileiro de Soja. 28 February to 4 March 2004. Foz do Iguassu, Brasil.

Campbell, C.L., and L.V. Madden. 1990. Introduction to plant disease epidemiology. 532 p. J. Wiley, New York, USA.

Carmona, M.A., M.E. Gally, y S.E. López. 2004. Roya asiática de la soja: patometría de epidemias en Argentina y caracterización morfológica de Phakopsora pachyrhizi (urediniosporas y teliosporas). Recomendaciones para su cuantificación e identificación. p. 291-295. XII Congreso Asociación Argentina de Productores en Siembra Directa (AAPRESID), Rosario, Santa Fe, Argentina.

D'Ambrogio, A. 1986. Manual de prácticas en histología vegetal. Hemisferio Sur, Buenos Aires, Argentina.

Dhingra, O.D., and J.B. Sinclair. 1985. Basic Plant Pathology Methods. $2^{\text {nd }}$. ed. 439 p. CRC Press, Boca Raton, Florida, USA.

Fehr, W.R., and C.E. Caviness. 1977. Stages of soybean development. Special Report: 80. Iowa State University, Iowa, USA.

Frederick, R.D., C.L. Snyder, G.L. Peterson, and M.R. Bonde. 2002. Polymerase chain reaction assays for the detection and discrimination of the soybean rust pathogens Phakopsora pachyrhizi and P. meibomiae. Phytopatology 92:217-227.

Furtado, G.Q., S.A.M. Alves, A.B.C.Czermainski, and S.J.R. Massolan. 2008. Preservation of Phakopsora pachyrhizi uredospores. J. Phytopathology 156:62-64.
Hartman, G.L., J.B. Sinclair, and J.C. Rupe. 1999. Rust. p. 24-26. In Compendium of Soybean Diseases. $4^{\text {th }}$ ed. 128 p. American Phytopathological Society, St. Paul, Minnesota, USA.

Herzog, L.Y., y E. Astegiano. 2004. Comportamiento de la roya de la soja ( $P$. pachyrhizi) en la región central de Santa Fe, Campaña 2003-2004. Experiencia RiiA. Información Técnica de cultivos de Verano. Publicación Miscelánea 102:71-74. Ediciones INTA, Centro Regional Santa Fe, EEA Rafaela, Rafaela, Argentina.

Hoppe, H.H., and E. Koch. 1989. Defense reactions in host and nonhost plants against the soybean rust fungus (Phakopsora pachyrhizi Syd.). Phytopathology 125:77-88.

Jennings, D.B., M.E. Daub, D.M. Pharr, and J.D. Williamson. 2002. Constitutive expression of a celery mannitol dehydrogenase in tobacco enhances resistance to the mannitol-secreting fungal pathogen Alternaria alternata. Plant Journal 32:41-49.

Leiva, R., R.G. Sandoval, y C. Briones. 2004. Evaluación de la viabilidad de las esporas de Puccinia sorghi sobre rastrojos de maíz dulce. 38 p. Disponible en http://hdl.handle. net/1950/2779 (Consulta 31 marzo 2011)

Lucas, J., and I. Knights. 1987. Spores on leaves: endogenous and exogenous control of development. p. 45-59. In Pegg G.F., Ayres P.G. (eds.). Fungal Infection of Plants. Cambridge University Press, Cambridge, UK.

Marchetti, M.A., F.A. Uecker, and K.R. Brombield. 1975. Uredial development of Phakopsora pachyrhizi in soybean. Phytopathology 65:822-823.

Marchetti, M.A., J.S. Melching, and K.R.Brombield. 1976. The effects of temperatures and dew period on germination and infection by uredospores of Phakopsora pachyrhizi. Phytopathology 66:461-463.

Maumary, R.L., R. Pioli, A. Ivancovich, E. Astegiano, and L. Herzog. 2006. Assessment of germination capacity of Phakopsora pachyrhizi urediniospores in laboratory conditions, in Argentina. Biocell 30(2):403.

Maumary, R.L. 2013. Condiciones ambientales y ontogénicas que modifican los patrones epidemiológicos de la interacción Phakopsora pachyrhizi-Glycine max. Tesis de Doctorado. Facultad de Ciencias Agrarias, Universidad Nacional de Rosario, Rosario, Argentina.

Miles, M.R., R.D. Frederick, and G.L. Hartman. 2003. Soybean Rust: Is the U.S. Soybean Crop at risk?. The American Phytopathological Society, Pilot Knob Road, St. Paul, Minnesota, USA. 
Ono, Y., P. Buritica, and J. Hennen. 1992. Delimitation of Phakopsora, Physophella and Cerotylium and their species on Leguminosae. Mycological Research 96:825-850.

Park, S., Chen, Z.-Y., A.K. Chanda, R.W. Schneider, and C.A. Hollier. 2008. Viability of Phakopsora pachyrhizi urediniospores under simulated southern Louisiana winter temperature conditions. Plant Dis. 92:1456-1462.

Pioli, R.N., M.V. Cambursano, and E.N. Morandi. 2005. Morphologic and pathometric characterization of the Asian soybean rust (Phakopsora pachyrhizi) in Santa Fe Province, Argentina. Plant Disease Note 89(6):684.

Rossi, R. 2002. First report of Phakopsora pachyrhizi Sidow, the causal organism of Soybean Rust in Misiones province, Argentina. Plant Disease (9):86.

Sousa, P.F.C., E. Alves, e H.Á. De Castro. 2006. Influência da temperatura no desenvolvimento de teliosporos de Phakopsora pachyrhizi em folíolos de soja. Summa Phytopathologica 32(3):227-233.

Tan, Y., Z. Yu, and J. Liu. 1994. Epidemical control of soybean rust caused by Phakopsora pachyrhizi (Syd). p. 36-48. In The Advance of Soybean Rust Research. Proceedings. Meeting held in Hubei Science and Technology Publishing House, Wuhan, Peoples Republic of China.
Voegele, R.T., and K. Mendgen. 2003. Rust haustoria: nutrient uptake and beyond. New Phytologist 159:93-100.

Voegele, R.T., C. Struck, M. Hahn, and K. Mendgen. 2001. The role of haustoria in sugar supply during infection of broad bean by the rust fungus Uromyces fabae. Proceedings of the National Academy of Sciences USA 98:8133-8138.

White, T.J., T. Bruns, S. Lee, and J. Taylor. 1990. Amplification and direct sequencing of fungal ribosomal RNA genes for phylogenetic. p. 315-322. In M.A. Innis, D.H. Gelfand, J.I. Stunski, and T.J. White. PCR Protocols: Guide to Methods and Applications. Academic Press Inc., New York, USA.

Yang, X.B. 2002. Soybean rust: epidemiology and management. In Anais Congresso Brasileiro de Soja e Mercosoja. EMBRAPA, Foz do Iguazú, PR, Brasil.

Yorinori, J.T. 2004. Country report and rust control strategies in Brazil. p. 447-455. F. Moscardi et al. (eds.). Proceedings of VII World Soybean Research Conference. IV International Soybean Processing and Utilization Conference, III Congresso Brasileiro de Soja. Embrapa Soja, Londrina, Paraná, Brasil.

Zambenedetti, E.B., E. Alves, E.A. Pozza, e D.V. Araújo. 2007. Germinação de urediniósporos do Phakopsora pachyrhizi em diferentes métodos de armazenamento. Summa Phytopathologica 33(1):83-85. 